\title{
The burden of injury
} in Brazil, 2003

Epidemiological Surveillance Center, State of São Paulo Department of Health, São Paulo, Brazil

CONTEXT AND OBJECTIVE: Since 1980, injuries have been the second biggest cause of death among the Brazilian population. This study aimed to analyze national data on fatal injuries and nonfatal injury hospitalization in Brazil, for 2003

DESIGN AND SETTING: This was a populationbased descriptive study, Brazil, 2003.

METHODS: Data from 126,520 fatal injuries and 733,712 nonfatal injuries seen at public hospitals were analyzed. The data were stratified by sex, age, intent and injury mechanism. Raw and age- and sex-specific rates were calculated per 100,000 individuals.

RESULTS: The raw injury mortality rate was $71.5 / 100,000(122.6 / 100,000$ for male and $22.0 / 100,000$ for female). For fatal injuries, the proportions of unintentional and intentional injuries were equal $(44.3 \%$ and $46.9 \%$, respectively). Homicides were the leading cause $40.3 \%$ overall $(28.8 / 100,000)$, followed by transport-related deaths, $26.2 \%$ overall $(17.0 / 100,000)$. For nonfatal injuries, the rate was $414.8 / 100,000$ and unintentional injuries were predominant $(88.9 \%)$. Overall, the leading cause was unintentional falls, accounting for $42.6 \%$ of victims treated in public hospitals (176.8/100,000). Transport-related injuries were second: $15.0 \%$ overall; $62.0 / 100,000$. Fractures comprised $46.7 \%$ of principal diagnoses at hospitals. The injury types in the fatal and nonfatal datasets varied according to sex and age. The highest rates were found among young males and elderly people.

CONCLUSIONS: Injury prevention activities need to be developed. To prevent deaths, homicide has to be addressed. Among hospitalized cases, falls are the most important problem. Traffic-related injuries play an important role in morbidity and mortality.

KEY WORDS: Mortality rate. Morbidity. Violence. Homicide. Accidents prevention. Traffic accidents.
INTRODUCTION

Injuries have been shown to account for a significant health burden on many countries around the world. ${ }^{1}$ Each year, injuries account for nearly 1 in 10 deaths worldwide and the mortality rates vary according to the country. Low and middle-income countries suffer disproportionately from reduced life expectancy and poor quality of life. ${ }^{2}$

Since the 1980s, injuries have become a major public concern in Brazil. Two recent reports from the World Health Organization have shown how important this problem is to Brazil, in comparison with other countries worldwide: in the World report on violence and health, ${ }^{3}$ Brazil had the third highest homicide rate and, according to the World report on road traffic injury prevention, ${ }^{4}$ Brazil was within the top five in terms of traffic-related mortality rates. In 2003, in Brazil, a total of 126, 520 people died because of injuries, accounting for $12.6 \%$ of all deaths, and there was a total of 733,712 discharges from public hospitals relating to injuries (6.3\% overall). ${ }^{5}$ For each fatal injury, 5.8 other people were hospitalized. ${ }^{5}$ National datasets from hospital emergency departments are not available in Brazil.

Developing an appropriate approach towards injury prevention depends on detailed knowledge about the epidemiology of injuries. In 2003, external causes were in third position among the causes of death for the whole population. Moreover, injuries were the leading cause for people aged between one and 44 years. According to the Brazilian Institute for Geography and Statistics, although life expectancy is increasing in Brazil (71.3 years in 2003), it may have been affected by two or three years because of premature mortality caused by homicides. ${ }^{6}$

口BJECTIVE

The objective of this study was to analyze national data on fatal injuries and nonfatal in- jury hospitalization in Brazil for 2003, thereby providing summary data from Brazil to share with people engaged in injury prevention activities in this country and around the world.

METHDDS

This was a population-based descriptive study that had the goal of providing an overview of the national data on fatal injuries and nonfatal injuries treated in public hospitals in Brazil. For mortality, the data are from the Mortality Information System (SIM). This database includes information from all death certificates filled out in the 26 States and Federal District of Brazil. For hospitalization, the data were obtained from the Hospitalization Information System of the Public Health System (SIH/SUS). Both datasets are maintained by Brazil's Ministry of Health. ${ }^{5}$

The case definition adopted for mortality was that this was related to death certificates on which the underlying cause of death was classified in Chapter XX of the International Classification of Diseases, Tenth Revision (ICD-10). Morbidity was taken to relate to the outcomes coded in Chapters XIX and XX of the ICD-10. With regard to injury intent, intentional injuries were considered to be those coded from X60 to Y09, undetermined intent was considered to be injuries coded from Y10 to $\mathrm{Y} 34$, and unintentional injuries were considered to be those with all other codes. The categories used for this analysis were:

- Transport-related injuries (V01-V89), which included: pedestrians (V01-V09), pedal cyclists (V10-V19), motorcycle riders (V20-V29) and motor vehicle occupants (V40-V79).

- Other external causes (W00-X59), which included: drowning (W65-W74), falls (W00-19), firelburns (X00-X19), firearm accidents (W32-W34) and accidental poisoning (X40-X49). 
- Intentional self-harm/suicides (X60-84), which included: intentional self-poisoning (X60-X69), self-hanging, strangulation and suffocation (X70), and self-harm by firearm (X72-X74).

- Assaults/homicides (X85-Y09), which included: assault by firearms (X93-X95) and assault by sharp objects (X99). Injuries relating to legal intervention were included in homicides/assaults.

- All other injuries were classified in the Other causes group.

For fatal and nonfatal injuries, the variables analyzed were sex, age and injury type. Raw and age- and sex-specific rates were calculated per 100,000 population. For nonfatal injuries, the categories included were the nature of the injury (principal diagnosis), the body region and the lethality of the injury. These were calculated according to age, sex, injury cause and injury intent.

RESULTS

\section{FATAL INJURIEE}

In 2003, in Brazil, a total of 126,520 people died from an injury: 106,608 were males $(84.3 \%)$ and 19,740 were females $(15.6 \%)$. Adolescents and adults aged 15 to 34 years accounted for $49.8 \%$ of the injury victims in Brazil. Table 1 shows the frequency of fatal injuries and rates per 100,000 individuals by age group, distributed according to selected types of injuries. The raw injury rate for the whole population was $71.5 / 100,000$ and the male rate $(122.6 / 100,000)$ was 5.6 times higher than the female rate $(22.0 / 100,000)$. The mortality rate for young adults aged to 20-24 years reached 121.2/100,000. Although the proportion of deaths among people aged
75 and more was not high $(5.3 \%)$, the agespecific rate was $180.7 / 100,000$.

Analysis combining age and sex showed that the highest injury rate was 221.5/100,000 among males aged 20-24 years. Analysis according to injury intent showed that the proportions of unintentional and intentional injuries were almost equal: $44.3 \%$ and $46.9 \%$, respectively. Undetermined injuries accounted for $8.8 \%$ of these deaths. Analysis of injury types showed that assaults accounted for $40.3 \%$ of all death victims, transport-related causes $26.2 \%$, falls $4.8 \%$, drowning $4.7 \%$ and intentional self-harm $6.2 \%$.

Transport-related injuries accounted for 30,149 of the fatal victims, and the highest proportion of these victims was among people aged 20 to 44 years. The raw death rate for the whole population was $17.0 / 100,000$; 28.0/100,000 for males and 6.4/100,000 for females (Table 1). The male/female ratio was 4.4. The fatality rate was greater for people aged 15 and over. Pedestrians accounted for $27.4 \%$ of these victims; the age group that showed the highest pedestrian death rates was people aged 65 and over. Motorcyclists accounted for $13.5 \%$.

Fall injuries did not represent a high proportion of the overall number of fatal injuries (6,010 deaths, $4.8 \%$ of total); the fatality rate was 3.4/100,000 overall, 4.9/100,000 among males and 2.0/100,000 among females. But the rate for people aged 75 and over was higher, reaching 51.6/100,000 (i.e. 15.2 times higher than the overall death rate due to falls) and the male/female ratio for this age group was 1.0 (Table 1). Analysis of the mechanism for these injuries showed that $45.8 \%$ of these cases were classified as unspecified falls; $9.3 \%$ was classified as falls from, out of or through buildings or structures.
Suicide victims comprised 7,839 and the suicide rate was $4.4 / 100,000$ overall: 7.2/100,000 among males and 1.8/100,000 among females. The male/female fatality ratio was 7.0. The highest suicide rates were found among people aged 45 to 54 years and 75 and over (Table 1). Analysis of the suicide mechanisms showed that hanging was the leading cause $(53.7 \%)$, followed by firearms (13.8\%).

In Brazil, in 2003, there were 50,980 homicide victims; most of them were among people aged 15 to 44 years. The homicide rates were $28.8 / 100,000$ for the whole population; $54.0 / 100,000$ for males and 4.4/100,000 for females. The male/female ratio was 12.3 . The peak was among people aged 20 to 24 years: the rate reached $69.2 / 100,000$ overall and $132.5 / 100,000$ for males in this group.

Firearm gunshots were the most frequent mechanism for homicides: weapons were used in $70.8 \%$ of all homicides. But this proportion varied according to sex and age group: it was lower for females $(53.6 \%)$ than for males $(72.2 \%)$; for children aged under five it was $19.0 \%$ and for people aged 75 and over it was $33.8 \%$. Sharp objects were used in $13.3 \%$ of these deaths.

\section{NONFATAL INJURIEB}

In 2003, 733,712 people were admitted to public hospitals in Brazil because of injuries. Table 2 shows the frequencies of nonfatal injuries and rates per 100,000 individuals by age group, distributed according to selected types of injury. The rate was 414.8/100,000 overall; among males it was $594.2 / 100,000$ and among females it was 240.9/100,000. The male/female ratio was 2.5 .

The proportions of hospitalized injury cases according to age group did not show any

Table 1. Fatal injuries according to age (number and rate/100,000), Brazil, 2003

\begin{tabular}{|c|c|c|c|c|c|c|c|c|c|c|c|c|}
\hline \multirow{2}{*}{$\begin{array}{l}\text { Age group } \\
\text { (years) }\end{array}$} & \multicolumn{2}{|c|}{ Transport } & \multicolumn{2}{|c|}{ Pedestrian } & \multicolumn{2}{|c|}{ Falls } & \multicolumn{2}{|c|}{ Suicide } & \multicolumn{2}{|c|}{ Homicide } & \multicolumn{2}{|c|}{ Total } \\
\hline & No. & Rate & No. & Rate & No. & Rate & No. & Rate & No. & Rate & No. & Rate \\
\hline$<5$ & 552 & 3.2 & 247 & 1.4 & 135 & 0.8 & - & - & 184 & 1.1 & 3,017 & 17.7 \\
\hline 5 to 9 & 719 & 4.2 & 385 & 2.2 & 80 & 0.5 & 6 & 0.0 & 100 & 0.6 & 1,846 & 10.7 \\
\hline 10 to 14 & 845 & 4.7 & 342 & 1.9 & 64 & 0.4 & 99 & 0.5 & 553 & 3.1 & 2,678 & 14.8 \\
\hline 15 to 19 & 2,621 & 14.0 & 489 & 2.6 & 112 & 0.6 & 658 & 3.5 & 7,943 & 42.5 & 13,955 & 74.7 \\
\hline 20 to 24 & 4,241 & 25.2 & 604 & 3.6 & 190 & 1.1 & 1,009 & 6.0 & 11,771 & 69.9 & 20,416 & 121.2 \\
\hline 25 to 34 & 7,034 & 23.5 & 1,197 & 4.3 & 502 & 1.8 & 1,710 & 6.1 & 14,871 & 53.0 & 28,772 & 102.6 \\
\hline 35 to 44 & 5,327 & 22.4 & 1,380 & 5.8 & 786 & 3.3 & 1,629 & 6.9 & 7,905 & 33.3 & 20,314 & 85.5 \\
\hline 45 to 54 & 3,900 & 23.8 & 1,155 & 7.0 & 754 & 4.6 & 1,217 & 7.4 & 3,736 & 22.8 & 13,145 & 80.1 \\
\hline 55 to 64 & 2,344 & 22.5 & 891 & 8.6 & 647 & 6.2 & 744 & 7.1 & 1,666 & 16.0 & 7,790 & 74.8 \\
\hline 65 to 74 & 1,649 & 25.2 & 802 & 12.2 & 779 & 11.9 & 469 & 7.2 & 703 & 10.7 & 5,549 & 84.8 \\
\hline 75 and + & 1,112 & 29.8 & 608 & 16.3 & 1,925 & 51.6 & 272 & 7.3 & 317 & 8.5 & 6,748 & 180.7 \\
\hline Total & 30,149 & 17.0 & 8,274 & 4.7 & 6,010 & 3.4 & 7,839 & 4.4 & 50,980 & 28.8 & 126,520 & 71.5 \\
\hline
\end{tabular}

Sao Paulo Med J. 2006; 124(4):208-13 
marked variation; most of these cases (49.6\%) were 20 to 54 years of age. But the rates did vary; the highest rate was among people aged 65 and over.

Analysis according to injury type showed a marked difference in comparison with fatal injuries: among the discharged injury cases, unintentional injury accounted for $88.9 \%$ overall. Falls accounted for $42.6 \%$, transportrelated $15.6 \%$, assaults $5.8 \%$, self-harm $1.4 \%$ and undetermined cause $3.9 \%$.

Nonfatal transport-related injuries comprised 109,691 of the discharged cases and, as found for fatal injuries, the highest proportion of victims was among people aged 15 to 34 years. The rate was $62.0 / 100,000$ overall; 96.7/100,000 for males and 28.4/100,000 for females; the male/female ratio was 3.4. Analysis according to age group showed that the highest rate was among people aged 20 to 24 years, followed by those aged 75 and over. Pedestrians accounted for $34.0 \%$ of these injured victims, and $22.4 \%$ were motorcyclists. Among pedestrians, the male/female ratio was 1.1, and the distribution according to age group was similar for all nonfatal transportrelated discharged cases.

The results from the analysis for motorcyclists differed from the overall transportrelated outcomes. The male/female ratio was higher (6.2), and the highest rates were found among adults aged 20 to 34 years. The lowest rates were found among children and elderly people.

Unintentional falls were the biggest cause of hospitalization, accounting for 312.693 of the discharged cases, i.e. $42.6 \%$ overall (Table 2). The rates were $176.8 / 100,000$ overall; 242.9/100,000 among males and $112.7 / 100,000$ among females; the male/female ratio was 2.1. Analysis according to age group showed that the rates were greater for older adults and people aged 75 and over, reaching a fall rate of $684.2 / 100,000$ for this latter age group, in which the hospitalization rate among females was higher than among males. Regarding the mechanisms for fall injuries, $50.6 \%$ were due to unspecified falls and $18.8 \%$ were due to falls classified as same-level falls due to slipping, tripping or stumbling. These findings for injury mechanisms were similar for males and females but not for age groups: falls from one level to another were more frequent among adults.

Nonfatal assaults accounted for 42,419 discharge cases $(5.8 \%$ of the total; $24.0 / 100,000)$. This was the only type of injury cause in which the number of fatalities was greater than the number of nonfatal victims. Five times more men were hospitalized because of assault $(35,255$ victims; $40.5 / 100,000)$ than women $(7,164 ; 8.0 / 100,000)$. As found for homicides, the highest percentage of nonfatal victims and the highest rates were identified among people aged 15 to 34 years. Among the nonfatal assault victims, the proportion of firearm use (30.2\% overall) was lower than for fatal assaults. Sharp objects were used in $25.3 \%$ and physical force was used in $14.9 \%$ of these cases. The use of firearms was more frequent for assaults among people aged 15 to 34 years, whereas among older adults, other means were more frequently used for committing these assaults.

Intentional nonfatal self-harm injuries were the cause of 10,305 discharged cases; the nonfatal rate was $5.8 / 100,000$ overall (7.3/100,000 among males and $4.4 / 100,000$ among females). Male victims $(6,328 ; 7.4 / 100,000)$ were 1.5 times more frequently hospitalized due to intentional self-harm injuries than were female victims
$(4,109 ; 4.6 / 100,000)$; the male/female ratio was 1.7. The age distribution differed from the fatal cases: the rate increased from the 25-34 age group to the 55-64 age group. Moreover, the mechanism differed from that of the fatalities: intentional self-poisoning accounted for $71.9 \%$ of these cases, especially exposure to alcohol (X65), pesticides (X68) and drugs, medications and biological substances (X64).

\section{HQGPITAL MORTALITY RATE AND PRINCIPAL DIAENDSIS}

The hospital mortality rate was $2.7 / 100,000$ overall; 2.8 among males and 2.2 among females. Analysis by age group showed that the highest rates were found among older people; adults aged $\geq 80$ years had the highest rate (7.3). Analysis combining sex and age group showed that the highest rates were among men, for all age groups. Table 3 shows the frequencies, ratios and hospital mortality rates for nonfatal injury cases, distributed according to selected injury types. The hospital mortality rate was almost twice as high among intentional injury cases (4.9) as among unintentional ones (2.7). Also, the rate varied according to the mechanism of injury, and the highest rates were found for intentional or unintentional injuries caused by firearms and intentional self-harm by hanging. The lowest rates were found among unintentional falls, fire/burns and poisoning. These rates were greater for men than for women, for all categories except for fire/burn injuries.

Table 4 shows frequencies, ratios and hospital mortality rates for nonfatal injury cases, distributed according to the nature of the injury. Fractures were the most common principal diagnosis; there were 342,479 victims, representing $46.7 \%$ of all discharged injury

Table 2. Nonfatal injuries according to age (number and rate/100,000), Brazil, 2003

\begin{tabular}{|c|c|c|c|c|c|c|c|c|c|c|c|c|}
\hline \multirow{2}{*}{$\begin{array}{l}\text { Age } \\
\text { group } \\
\text { (years) }\end{array}$} & \multicolumn{2}{|c|}{ Transport } & \multicolumn{2}{|c|}{ Pedestrian } & \multicolumn{2}{|c|}{ Falls } & \multicolumn{2}{|c|}{$\begin{array}{l}\text { Intentional } \\
\text { self-harm }\end{array}$} & \multicolumn{2}{|c|}{ Assault } & \multicolumn{2}{|c|}{ Total } \\
\hline & No. & Rate & No. & Rate & No. & Rate & No. & Rate & No. & Rate & No. & Rate \\
\hline$<5$ & 3,902 & 22.8 & 1,955 & 11.4 & 17,440 & 102.0 & 332 & 1.9 & 998 & 5.8 & 42,376 & 247.9 \\
\hline 5 to 9 & 6,695 & 38.8 & 3,176 & 18.4 & 30,401 & 176.3 & 284 & 1.6 & 989 & 5.7 & 57,556 & 333.7 \\
\hline 10 to 14 & 6,976 & 38.6 & 2,697 & 14.9 & 27,495 & 152.2 & 502 & 2.8 & 1,446 & 8.0 & 54,328 & 300.6 \\
\hline 15 to 19 & 12,056 & 64.5 & 3,341 & 17.9 & 23,069 & 123.4 & 1,122 & 6.0 & 5,729 & 30.7 & 64,520 & 345.2 \\
\hline 20 to 24 & 16,816 & 99.9 & 3,996 & 23.7 & 26,236 & 155.8 & 1,342 & 8.0 & 8,025 & 47.7 & 80,251 & 476.5 \\
\hline 25 to 34 & 23,708 & 84.5 & 6,315 & 22.5 & 45,368 & 161.7 & 2,258 & 8.1 & 11,099 & 39.6 & 128,126 & 456.8 \\
\hline 35 to 44 & 16,272 & 68.5 & 5,363 & 22.6 & 40,705 & 171.3 & 2,089 & 8.8 & 6,714 & 28.2 & 102,987 & 433.3 \\
\hline 45 to 54 & 10,257 & 62.5 & 4,004 & 24.4 & 32,770 & 199.6 & 1,293 & 7.9 & 3,755 & 22.9 & 74,573 & 454.3 \\
\hline 55 to 64 & 5,836 & 56.0 & 2,620 & 25.1 & 23,585 & 226.4 & 557 & 5.3 & 1,849 & 17.7 & 49,572 & 475.8 \\
\hline 65 to 74 & 4,057 & 62.0 & 2,119 & 32.4 & 20,078 & 306.7 & 322 & 4.9 & 985 & 15.0 & 38,289 & 584.8 \\
\hline 75 and + & 3,121 & 83.6 & 1,693 & 45.3 & 25,546 & 684.2 & 204 & 5.5 & 830 & 22.2 & 41,134 & $1,101.6$ \\
\hline Total & 109,696 & 62.0 & 37,279 & 21.1 & 312,693 & 176.8 & 10,305 & 5.8 & 42,419 & 24.0 & 733,712 & 414.8 \\
\hline
\end{tabular}


cases. Analysis according to sex showed that there were more men than women in almost all diagnoses, except for poisoning (4,746 men and 8,049 women). Analysis according to age group showed differences for the age groups at the extremities, in comparison with the others. Among children aged under five, the number of intracranial injuries was similar to the number of fractures in other bones and the proportion of burns/corrosion was higher than in all other age groups. Among people aged 75 and over, fractures were the most important cause of hospitalization. The three diagnoses that showed the highest hospital mortality rates were intracranial injury (10.2), injury of other internal organs (7.9) and fractures of the neck, thorax and pelvis (3.3).

DISCUSSIRN

Fatal and nonfatal injuries are a major public health problem for all Brazilian residents; in 2003 , approximately 157,000 people died as a result of injuries and, for each death, almost six people were treated for an injury in a Brazilian public hospital. This proportion is lower than in the United States, where for every death, around 10 people were hospitalized and/or transferred to a specialized medical care unit, and 178 people were treated and released from an emergency department. ${ }^{8}$ This comparison has to be carefully considered because these numbers may reflect better access to medical care in a developed country, or different policies regarding admissions of injured cases to hospitals.

Violence, particularly homicides, has become a major public concern for Brazilian society. Between 1980 and 2002, the homicide rate more than doubled in Brazil. ${ }^{9}$ The results from the present study showed that assaults had a greater impact on mortality than on morbidity, which is probably an expression of the high proportion of firearms used in assaults. These weapons are more likely to result in death than any other means. ${ }^{10}$ In big cities in Brazil, this proportion may be higher, because studies based on medical examiners' records have shown that over $90 \%$ of homicides are perpetrated with firearms in urban areas such as São Paulo or Recife. ${ }^{9,11}$ In addition, a trend analysis study on firearm mortality in Brazil during the 1990s showed that the homicide mortality rate increased by $27.5 \%$ and the firearm homicide mortality rate increased by $72.5 \%$, thus indicating the large contribution of firearms towards the increasing trend of homicide deaths in Brazil. ${ }^{12}$

Brazil has implemented some significant preventive measures at the national level over the past few years to address this problem. One of these was the Disarmament Statute, approved by the Brazilian Congress in December 2003, which is a very strict law that makes it illegal to carry and own firearms, throughout the country, except for the police and armed forces. ${ }^{13}$ In addition, in 2004, a campaign to motivate the Brazilian public to give up their weapons to the judicial authorities was implemented.

Table 3. Nonfatal injuries according to mechanism of injury (number, \% and rate/100,000) and hospital mortality rate. Brazil, 2003

\begin{tabular}{lcccc}
\hline Mechanism of injury & Number & $\%$ & $\begin{array}{c}\text { Rate/100,000 } \\
\text { population }\end{array}$ & $\begin{array}{c}\text { Hospital } \\
\text { mortality rate }\end{array}$ \\
\hline All unintentional & 652,135 & 88.9 & 368.7 & 2.7 \\
\hline Transport-related & 109,696 & 15.0 & 62.0 & 4.5 \\
Pedestrian & 37,279 & 5.1 & 21.1 & 5.4 \\
Pedal cyclist & 10,646 & 1.4 & 6.0 & 2.5 \\
Motorcycle rider & 24,604 & 3.4 & 13.4 & 3.5 \\
Motor-vehicle occupant & 14,221 & 1.9 & 8.0 & 6.0 \\
Motor-vehicle unspecified & 18,068 & 2.5 & 10.2 & 4.5 \\
Other external causes & 491,640 & 67.0 & 278.0 & 2.0 \\
Falls & 312,693 & 42.6 & 176.8 & 1.7 \\
Drowning & 2,111 & 0.3 & 1.2 & 2.1 \\
Fire/burns & 21,842 & 3.0 & 12.4 & 4.2 \\
Firearms & 6,596 & 0.9 & 3.7 & 7.5 \\
Poisoning & 9,315 & 1.3 & 5.3 & 2.1 \\
\hline All intentional & 52,724 & 7.1 & 29.8 & 4.9 \\
\hline Self-harm & 10,305 & 1.4 & 5.8 & 3.4 \\
Poisoning & 7,391 & 1.0 & 4.2 & 2.7 \\
Firearms & 549 & 0.1 & 0.3 & 12.9 \\
Assault & 42,419 & 5.8 & 24.0 & 5.3 \\
Firearms & 12,827 & 1.7 & 7.3 & 10.1 \\
Slashing/stabbing & 1,522 & 0.2 & 0.9 & 2.8 \\
\hline Undetermined & 28,853 & 4.0 & 16.3 & 2.5 \\
\hline Total & $\mathbf{7 3 3 , 7 1 2}$ & 100.0 & 414.8 & $\mathbf{2 . 7}$ \\
\hline
\end{tabular}

Table 4. Nonfatal injuries according to nature of injury (number and \%) and hospital mortality rate, Brazil, 2003

\begin{tabular}{lccc}
\hline Nature of injury & Number & $\%$ & $\begin{array}{c}\text { Hospital } \\
\text { mortality rate }\end{array}$ \\
\hline Fracture of skull and facial bones & 28,745 & 3.9 & 0.7 \\
Fracture of neck, thorax and pelvis & 15,424 & 2.1 & 3.3 \\
Fracture of femur & 58,834 & 8.0 & 2.4 \\
Fractures of other bones & 240,603 & 32.8 & 0.1 \\
Fractures involving multiple regions & 1,873 & 0.3 & 1.9 \\
Dislocations, sprains and strains & 30,043 & 4.1 & 0.4 \\
Intracranial injury & 94,549 & 12.9 & 10.2 \\
Injury of internal organs & 26,490 & 3.7 & 7.9 \\
Crushing and traumatic amputations & 12,552 & 1.7 & 2.3 \\
Burns and corrosion & 32,387 & 4.4 & 2.5 \\
Poisoning by drugs, medications and biological substance & 12,795 & 1.7 & 2.0 \\
Toxic effects of non-medicinal substances & 41,238 & 5.6 & 1.8 \\
Maltreatment syndromes & 154 & 0.0 & 0.7 \\
Other injuries & 136,919 & 18.7 & 2.7 \\
Information missing regarding nature of injury & 1,106 & 0.2 & 1.6 \\
\hline Total & $\mathbf{7 3 3 , 7 1 2}$ & 100.0 & $\mathbf{2 . 7}$ \\
\hline
\end{tabular}

Among the unintentional injuries, transport-related events had a great impact on both fatal and nonfatal injuries. The World Health Organization has reported that $88 \%$ of deaths due to transport accidents happen in low and middle-income countries, where the numbers of cars are lower than the numbers in developed countries. ${ }^{4}$ Much greater preventive efforts need to be made, in order to reduce the deaths and disabilities associated with motor 
vehicle injuries among adolescents, young adults and the elderly. Pedestrians ranked the highest among traffic-related injuries, and therefore specific strategies need to be implemented to deal with this problem.

The finding that half of the cases of injuries admitted to public hospitals were due to falls suggests the need for intervention activities to be planned and implemented, in order to reduce this problem, especially among older people. The demographic structure has been changing over recent decades in Brazil, probably due to declines in infant mortality rate and fertility rate. ${ }^{14,15}$ This change has been having a significant impact on all aspects of health statistics and medical care, and there is a very urgent need to address the question of injuries among this age group. There is extensive literature on successful measures for preventing falls among the elderly. ${ }^{16,17}$ Since most of these events have been classified as unspecified falls, there is a need to improve the information and carry out further research, in order to identify how such injuries are occurring and the risk factors involved in such events.

The suicide rate in Brazil is lower than in developed countries. ${ }^{3}$ The age-adjusted suicide rate in the United States in 2001 was 10.7/100,000 people, ${ }^{18}$ i.e. 2.4 times higher than in Brazil. Studies have suggested that it is important to provide support and treatment for people who try to commit suicide and require hospital admission, in order to reduce the risk of further attempts. ${ }^{19}$

The quality of the Brazilian Mortality Information System (SIM) is considered good. However, the data relating to nonfatal injuries should be interpreted with certain restrictions. First, these data represent outcomes from public hospitals and do not include data relating to injured individuals treated in private hospitals. In Brazil, only $24.6 \%$ of the whole population has private health insurance (according to the Supplementary National Health Agency; data from 2003). ${ }^{20}$ Public hospitalization is estimated to represent between $88 \%$ (northern region of Brazil) and 66\% (southern region) of all hospitalization. ${ }^{20}$ Second, because the dataset is very large, it is difficult to obtain nationwide validation and therefore there are no studies available on the quality of the information system. Finally, another potential limitation to the present study is in relation to the high proportion of fall injuries, because assault-related injuries such as intimate partner violence or child maltreatment may have been included in this category. Medical providers may not have asked about or recorded whether or not violence was involved.

Population-based surveillance for emergency departments is also needed in order to monitor injuries and for use in prevention program planning. In Brazil, most emergency departments and health clinics are part of the public health system, but establishing an injury surveillance system remains a challenge. Even in the United States, where twenty-six states have hospital discharge datasets, only nine of them have emergency department datasets available in hospitals. ${ }^{8}$

These results highlight that injuries are one of the most serious health problems in Brazil. The consequences for Brazilians are many and various. Reducing the burden of injuries is a big challenge for public health in Brazil, and understanding the magnitude and characteristics of the problem is the best way to develop injury prevention programs. Brazil has accurate and timely mortality data. Also, timely data on hospitalization is available. Through this, Brazil has been making efforts to promote data analysis in its different states.

CDNCLUSION

The findings from the present study show that the main causes of fatal injuries differ from those that lead to hospitalization. Therefore, in establishing public policies aimed at preventing and monitoring injuries, not only should the mortality data be considered, as usual, but also the hospitalization data needs to be taken into account. 
1. Krug EG, Sharma GK, Lozano R. The global burden of injuries. Am J Public Health. 2000;90(4):523-6.

2. Hofman K, Primack A, Keusch G, Hrynkow S. Addressing the growing burden of trauma and injury in low- and middle-income countries. Am J Public Health. 2005;95(1):13-7.

3. Krug EG, World Health Organization. Statistical Annex. In Krug EG, Dahlberg LL, Mercy JA, Zwi AB, Lozano R, editors. World report on violence and health. Geneva: World Health Organization; 2002. p. 300-28

4. Peden MM, World Health Organization. Statistical Annex. In: Peden MM, Scurfield R, Sleet D, editors. World report on road traffic injury prevention. Geneva: World Health Organization, 2004. p. $188-94$

5. Brasil. Ministério da Saúde. Datasus. Informaçōes de Saúde. Available from URL: http://tabnet.datasus.gov.br/tabnet/tabnet. htm. Accessed in 2006 (May 15).

6. Brasil. Ministério do Planejamento, Orçamento e Gestâo Instituto Brasileira de Geografia e Estatística. Tábuas Completas de Mortalidade - 2003. Available from URL: www.ibge.gov.br. Accessed in 2006 (May 15).

7. World Health Organization. International statistical classification of diseases and related health problems. $10^{\text {th }}$ rev. Geneva: World Health Organization; 1992. Available from URL: http:/ www3.who.int/icd/currentversion/fr-icd.htm. Accessed in 2006 (Jul 10).

8. Vyrostek SB, Annest JL, Ryan GW. Surveillance for fatal and nonfatal injuries-United States, 2001. MMWR Surveill Summ. 2004;53(7) 1-57.

9. Centers for Disease Control and Prevention (CDC). Homicide trends and characteristics-Brazil, 1980-2002. MMWR Morb Mortal Wkly Rep. 2004;53(8):169-71.
10. Fingerhut LA, Chirstoffel KK. Firearm-related death and injury among children and adolescents. Future Child. 2002;12(2):24-37.

11. Peres MFT, Santos PC. Mortalidade por homicídios no Brasil na década de 90: o papel das armas de fogo. [Trends of homicide death in Brazil in the 90s: the role of firearms]. Rev Saúde Pública. 2005;39(1):58-66.

12. Falbo GH, Buzzetti R, Cattaneo A. Homicide in children and adolescents: a case-control study in Recife, Brazil. Bull World Health Organ. 2001;79(1):2-7.

13. Brasil. Estatuto do desarmamento. Lei n. 10.826, de 22/12/03. Brasilia: Câmara dos Deputados, Coordenaçăo de Publicaçóes, 2004. Available at: http://www.camara.gov.br/internet/infdoc/Publicacoes/ $\mathrm{html} / \mathrm{pdf} /$ Desarmamento.pdf. Accessed in 2006 (May 15).

14. Lotufo PA. Brazil is getting older: some lessons from the Bambui Health and Aging Study. Sao Paulo Med J. 2004;122(3):79-80.

15. Gawryszewski VP, Koizumi MS, Mello-Jorge MH. As causas externas no Brasil no ano 2000: comparando a mortalidade e a morbidade. [Morbidity and mortality from external causes in Brazil, 2000]. Cad Saude Publica. 2004;20(4):995-1003.

16. Robertson MC, Campbell AJ, Gardner MM, Devlin N. Preventing injuries in older people by preventing falls: a meta-analysis of individual-level data. J Am Geriatr Soc. 2002;50(5):905-11.

17. Binder S. Injuries among older adults: the challenge of optimizing safety and minimizing unintended consequences. Inj Prev. 2002;8(Suppl 4):IV2-4.

18. Anderson RN, Minino AM, Fingerhut LA, Warner M, Hainen MA. Deaths: injuries, 2001. Natl Vital Stat Rep. 2004;52(21):1-86.

19. Gibb SJ, Beautrais AL, Fergusson DM. Mortality and further suicidal behavior after an index suicide attempt: a 10-year study. Aust N Z J Psychiatry. 2005;39(1-2):95-100.
20. IBGE. Instituto Brasileiro de Geografia e Estatística. Diretoria de Pesquisas, Coordenaçăo de Trabalho e Rendimento. Pesquisa Nacional por Amostra de Domicílios 2003. Tabela 32. Populaçâo residente, por cobertura de plano de saúde, tipo do plano de saúde principal e situaçăo de titular ou dependente, segundo as Unidades da Federação - Brasil - 2003. Available from URL: http://www.ibge.gov.br/home/estatistica/populacao/trabalhoerendimento/pnad2003/saude/tab32.pdf. Accessed in 2006 (Aug 15).

Sources of funding: None Conflict of interest: None

Date of first submission: September 5, 2005

Last received: August 3, 2006

Accepted: August 15, 2006
AUTHOR INFORMATIDN

Vilma Pinheiro Gawryszewski, MD, PhD. Epidemiological Surveillance Center, State of São Paulo Department of Health, São Paulo, Brazil.

Eugênia Maria Silveira Rodrigues, MD, PhD. Health Surveillance Department, Ministry of Health, São Paulo, Brazil.

\section{Address for correspondence:}

Vilma Pinheiro Gawryszewski

Departamento de Saúde do Estado de São Paulo, Centro de Vigilância Sanitária

Av. Dr. Arnaldo, 351 - Sala 609 - Cerqueira César

São Paulo (SP) - Brasil - CEP 01246-000

Tel. (+55 11) 3082-8216

Cell. $(+55$ 11) $9954-925$

Fax (+55 11) 3081-9161

E-mail: vilmapg@saude.sp.gov.br

Copyright @ 2006, Associação Paulista de Medicina

\section{O impacto das causas externas de morbidades no Brasil, 2003}

CONTEXTO E OBJETIVO: A partir da década de 80, a morbimortalidade por causas externas no Brasil se tornou um desafio para a saúde pública. O objetivo deste estudo é analisar os dados de mortes e internações hospitalares no Sistema Unico de Saúde devido às causas externas no ano de 2003, último ano disponível.

TIPO DE ESTUDO E LOCAL: Estudo descritivo com base populacional, realizado no Brasil.

MÉTODOS: O universo das 126.520 mortes e 733.712 internações por causas externas foi analisado. Os bancos de dados utilizados foram o Sistema de Informações de Mortalidade (SIM/DATASUS) e o Sistema de Internações Hospitalares (SIH). Os dados foram estratificados por sexo, idade, tipo de causa externa e natureza da lesão. Taxas calculadas por 100.000 habitantes.

RESULTADOS: A taxa de mortalidade por causas externas foi 71,5/100.000 (122,6/100.000 para os homens e 22,0/100.000 para as mulheres). Na mortalidade observou-se um equilíbrio entre a proporção de lesões intencionais e não-intencionais (44,3\% e $46,9 \%$, respectivamente). Os homicídios representaram $40,3 \%$ do total de mortes $(28,8 / 100.000)$, seguido pelos acidentes de transporte, $26,2 \%$ do tota $(17,0 / 100.000)$. A taxa de morbidade foi de $414,8 / 100.000$, as lesões não-intencionais representaram $88,9 \%$. As quedas foram a maioria $(42,6 \%$ do total; $176,8 / 100.000)$, seguidas pelos acidentes de transporte, $15,0 \%$ do total, $62,0 / 100.000$. As fraturas foram o diagnóstico mais comum nas internações.

CONCLUSÕES: Para prevenir mortes, estratégias para reduzir as agressões devem ser desenvolvidas; para prevenir hospitalizações, medidas para redução das quedas devem ser priorizadas.

PALAVRAS-CHAVE: Coeficiente de mortalidade. Morbidade. Violência. Prevenção de acidentes. Homicídio. Acidentes de trânsito. 